\title{
РЕКОНСТРУИСАЊЕ ДУШЕ КУЛТУРНОГ ДОБРА И НАШЕГ ДОЖИВЉАЈА НАСЛЕЪА У ПРОЦЕСУ ДИГИТАЛНОГ ТРЕЗОРИРАЊА
}

\author{
У одређеној мери али на различите начине \\ сви смо у процепу између нужности \\ да будемо део напретка и потребе \\ да сачувамо нашу баштину (Пол Рикер)
}

\section{Сажетак}

Дигитализација је изазов бољем разумевању и коришћењу наслеђа. Свако наслеђе постаје нечија баштина тек када неко препозна основна својства добра у њему. Усвојити нешто као своју баштину пре свега указује на то да се у нашем сећању прошлост оживљава као поновна потврда вредности добра и лепоте. Културна добра представљају белеге одржања хуманистичког одгајања личности. У алгоритму би датотеке извора за музеализацију биле основ за улазак у процесе реконструисања душе културног добра и нашег доживљаја наслеђа као свог имања. Доступност дигиталног превода било ког драгоценог садржаја из фонда духовне баштине ново је искуство, без премца у историји.

Кључне речи: наслеђе, баштина, културно добро, дигитализација, савремена презентација наслеђа, анимација, комуникација, онлајн доступност

На конференцији одржаној у Бриселу октобра $2011^{1}$ примарна тема била је дигитализација културе са недвосмисленом тенденцијом њене глобализације, тржишног позиционирања и повећања реалних потенцијала самоодрживости, односно дефинисање пројеката, програма и активности који праве сопствене финансије.

1 Mercer, C., Which skills for culture in globalised and digitised world? U: European Cultural Forum, Brussels: European Cultural Forum, 2011, (uvodno izlaganje na European Cultural Forum, Brisel, 20-21 oktobar 2011. 
Дигитализација и могућност онлајн приступа културном материјалу могу да олакшају и обогате учешће у културном животу великом делу становништва. Могућност онлајн приступа фондовима библиотека, на пример, значајно олакшава доступност књига, док посећивање музејских интернет сајтова подстиче кориснике на посету и на учешће у културном животу. Стари циљеви културних политика постижу се новим активностима.

Као императив савременог дигитално обликованог доба, електронска презентација културног наслеђа убрзано се ствара у већини европских и других развијених земаља.

Иако се у образлагању огромне стратешке важности и практичних предности дигитализације културне баштине стручњаци радо позивају на аргументе као што је заштита и трајно чување културних добара, те обавеза према будућим поколењима, чини се да је управо онлајн доступност пресудни бенефит овог посла. Јесте за науку важна остварена могућност квалитетнијег изучавања и релативно лаког комплетирања фондова - посредована оком моћног ЗД скенера, презентација споменичких и других објеката културе превазилази најдетаљније описе друге врсте - али је добитак најширег аудиторијума неупоредив. Доступност дигиталног превода било ког драгоценог садржаја из фонда духовне баштине ново је искуство, без премца у историји. ${ }^{2}$

У дигитализовању културне баштине у Србији највише је појединачно учинила Народна библиотека Србије, иначе трећа европска библиотека по броју дигитализованих старих рукописа. Дигитална Народна библиотека Србије изграђена је у складу с принципима отвореног приступа знању и информацијама и њена грађа представља јавно национално добро.

Корисницима се нуди око пола милиона дигиталних докумената организованих у преко четрдесет дигиталних збирки које су сврстане према типовима грађе у изворном облику: Ћирилски рукописи, Стара и ретка књига, Књиге, Новине и часописи, Картографска грађа, Гравире и ликовни материјали, Фотодокумента, Плакати и до-

2 Vukićević, Vuk, Digitalizacija kulturnog nasleđa u funkciji ostvarivanja ciljeva kulturne politike, Kultura, 30/2011, str. 165-182. 
кументациони материјал, Музикалије и фонодокументи, Каталози и библиографије.

Дигитална и мултиетничка револуција обележавају време у којем живимо: обе чине да се лични идентитет одваја од традиције, корена.

Поставља се питање да ли је дигитално ускладиштење које није оријентисано натрајност повезано сједном сасвим новом димензијом брисања памћења која надмашује све досадашње форме културне амнезије? Тај однос између пролазног и трајног трага сећања постао је део пројекта Меморија света који подржава UNESCO. Ради се о програму за остварење колективног памћења света у који би били укључени значајни документи у писаној форми, тону, слици и филму. И ту долазимо до кључног проблема тј. виртуелног питања: ко данас, у епохи дигиталне комуникације и још увек неразјашњеног (можда и неразјашњивог) начина дугорочног архивирања података, одлучује о томе чега ћемо се сутра сећати? ${ }^{3}$

Критичка реконструкција савременог дискурса сећања (и заборављања) последњих деценија је заузела централну улогу у већини друштвених и хуманистичких наука. Појам сећања се пробио у само средиште савременог мишљења - студије сећања (Memory Studies).

Истрајавање само на чињеници и статусу културног добра из прошлости није довољно, то је тек полазна основа за креацију и интеракцију с контекстом. С тим у вези, функционална примена ICNT и дигитализације обећава знатне предности. То је отворен домен за вишедимензионално креирање и дистрибуцију културног наслеђа као активног и интерактивног садржаја у свим контекстима. ${ }^{4}$

Истицање да би крајњи циљ дигитализације културног наслеђа требало да буде интеграција дигиталних садржаја у националне и међународне портале културне баштине у сврху унапређења његове

3 Божић, Јадранка, Реанимација артефаката културне баштине као антипод репродукцији - Критичка реконструкција савременог дискурса сећања као централни, организациони појам савременог мишљења, Хоризонти светског и европског библиотекарства у дигиталном добу : зборник радова са међународне научне конференције, Београд, 27-28. октобар 2011. / [организатор конференције Библиотекарско друштво Србије] ; уредници Весна Црногорац и Весна Ињац; стр. 228 и даље Исто. 
доступности и коришћења проузроковало је промену парадигме и мотива за дигитализацију која све више постаје средишња активност у којој је управо стварање огромних база података на интернету водећи механизам. Развијање огромних културних агрегатора као што је нпр. Еуропеана и разумевање покретача за дигитализацију културног наслеђа - националне и регионалне културне политике, као и очекивања јавности (корисника) - омогућава да се истраже и последице ових активности, како у дефинисању националних културних политика, тако и у дефинисању професионалног става према остваривању различитих задатака у оквиру самих културних институција. ${ }^{5}$

Портал Еуропеана отворен је 2008. године. Замишљен као дигитална библиотека, музеј и архив, он данас омогућава јединствени приступ до више од 20.000 милиона дигитализованих објеката (текстова, слика, аудио и видео записа и виртуелних ЗД репрезентација) из преко 2.200 културних институција и организација широм Европе.

Културна добра представљају белеге одржања хуманистичког одгајања личности: добро је оно чему нас води љубав према знању. Задовољство у сазнању открива сваком појединцу сву лепоту света. Ово темељно својство културе сећања у суштинском смислу одређује трезоре памћења као живе процесе присећања и као материјалне белеге подсећања. ${ }^{6}$

Дакле, природа културног наслеђа подразумева да се може рачунати на трезорирање тек када се дигитализује њена нематеријална и њена материјална - појавна структура. Сходно томе, једина употребљива алатка у домену дигиталног трезорирања је хипертекст: само ако се феномен културног добра операционализује као постпроцесна структура, могуће је поставити ефикасан алгоритам концептуалне иницијације - материјалних подстицаја - сећајућег продукта. Најмање због тога што смо иначе сви свесни да сам физички објекат из корпуса баштине сам за себе ништа не говори, напротив да је чак и упркос доминантним културним кодовима којим се чита

5 Илиева Николовска, Анита, Документација музејских колекција, Читалиште, 22/2013, стр. 39-40 Vidi: Bulatović, Dragan, Digitalizacija kao izazov boljem razumevanju i korišćenju nasleđa, tekst predavanja (rukopis), 2014. http://www.pamtimzlatibor.com/sites/default/files/Dr_ Dragan_Bulatovic_najava.pdf 
примарно значење. Другим речима: мора се трезорирати не само предмет или догађај који изазива носталгични процес већ и контекст у којем читав процес добија посебну вредност, вредност која излази из поштовања сећања. Култура сећања појединца је основ богатства памћења заједнице. Тај поредак не сме да буде поремећен у процесу дигиталног трезорирања тиме што ће се овај претворити у голо имитирање аналогног пресликавања - узимања лика, спољащњих обриса са предмета који чине корпус баштине, тј узимања тела без душе. У алгоритму би датотеке извора за музеализацију - закона, правила, обичаја; документа свакодневице јавног и приватног, били основ за улазак у процесе реконструисања душе културног добра и нашег доживљаја наслеђа као свог имања. ${ }^{7}$

Свако време и вредни људи који постоје и трају у њему на свом животном и радном простору настоје да упамте, забележе и сачувају од заборава много тога. Некад су то биле тзв. високе културне форме, артефакти којима се приписивао посебан значај за конституисање културног идентитета неке групе, народа, краја или већих територијалних целина. Постепено су у круг тих вредних форми почеле улазити и друге ствари, наизглед не толико битне у тренутку кад су настајале и биле забележене, али су тек потоње генерације у времену које је следило долазиле до спознаје да су једнако занимљиви и битни записи малих, непознатих људи.

Развојем технологије, нарочито дигиталних информационих технологија нашег доба, отвориле су се неслућене могућности похрањивања и коришћења свих врста записа - од традиционалних материјалних и писаних форми до звучних, те визуелних записа на фотографији, филму, видеу и тсл. Наше време ужурбано настоји да пренесе на дигиталне записе мноштво података, а посебно оне који доприносе очувању и презентовању културне баштине. Требало би сву ову драгоцену грађу сачувати, обрадити и представити urbi et orbi (граду и свету).

Због своје глобалности, интерактивности, богатства вербалних и невербалних симбола, променљивости и преправљивости, интернет има велики иновативни потенцијал. Развој нових технологија и интер-

7 Исто 
нета омогућио је нове активности, међу којима је и дигитализација културног наслеђа.

UNESCO је дао елегантну дефиницију баштине: "Баштина је оно што смо наследили из прошлости, оно што живимо данас и оно што предајемо наредним генерацијама. То је поклон из прошлости за будућност"8. "Наравно, појам баштине углавном разумемо у овом оптимистичком светлу, али морамо бити опрезни”, примећује Милан Попадић. “Није све што смо наследили из прошлости и наменили за будућност баш тако оптимистично, ведро и позитивно. Такође, поклонити неком нешто леп је гест, али и поклона има разних." ${ }^{\prime 9}$ Сетимо се само тројанског коња и отуд потекле пословице: Чувај се Данајаца и кад дарове носе.

Баштина је нешто што се чини, иако не постоји један тачно дефинисан чин већ распон активности које обухватају памћење, комеморацију, комуникацију и преношење знања или сећања, једнако тако и афирмацију и изражава идентитете друштвених и културних вредности и значења. ${ }^{10}$

Римски правни институт patrimoniuma подразумевао је неотуђиво право на наслеђе од предака. Пренет из легислативне равни, коју никад није у потпуности напустио, појам баштине у ширем хуманистичком контексту добија општије значење трезора запамћених материјалних и нематеријалних носилаца вредности и норми. Ове вредности и норме претрајале из прошлости нису, међутим, увек у сагласју са савременим жељама или приликама у којима онај који их баштини делује. Стога у контексту свакодневног живота баштину можемо посматрати као сложени фактор који окупља различите, понекад и супротстављене пориве.

Време баштине и време човека није исто. Баштина је оно што претрајава време, а човек то, ипак, није у стању. Отуда и његова свакодневна брига за сведочанства. Институција баштине у смислу трезора запамћених материјалних и нематеријалних носилаца вредности и норми изум је модерног доба.

$8 \quad$ World Heritage Information Kit, Paris: UNESCO World Heritage Centre, 2008, 5.

9 Popadić, Milan, Čiji je Mikelanđelov David?: baština u svakodnevnom životu, Beograd, 2012.

10 Smith, Laurajane, All Heritage is Intangible: Critical Heritage Studies and Museums, Reinwardt Academy; Amsterdam School of Arts, 2011, 23. 
Памћење je conditio sine qua non баштине и баштињења. Али и свакодневице. Свакодневица је ниво реалности састављен од ствари које су нам непрестано пред очима и које нам се урезују у памћење. Баштина тако испуњава свакодневицу, као што и свакодневица одржава трајање баштине. Ако баштина заиста јесте оно из прошлости што чувамо за будућност, свакодневица нас учи да баштина, као и човек, мора живети пре свега у данашњици.

Теорија баштине има вишеструк циљ: послужити разумевању феномена баштине и улоге баштинских институција, бити критика струке и помоћи будућност струке. Концепт баштине, тренутно изузетно модеран у оквиру европске и светске музеологије, настоји да обухвати укупно природно и културно наслеђе. Музеј/заштићена баштина је институција која сама по себи производи значење различито од оног које његов садржај (предмет, објекти, простор итд.) има у култури из које потиче и који се мења у складу с променом друштвено/културног контекста. Музејски предмет има различита значења у различитом времену/простору, а његово измештање из природног и културног окружења и смештање у музејску збирку придодаје му нови скуп значења. Дакле, суштина заштите баштине требало би да буде управо у читању скупа њених разноврсних значења, од кога ће зависити и употреба/живот те баштине у свакодневици.

Појам културне баштине укључује наслеђе физичких артефакта материјалне, руком сачињене културе, у коју спадају и природне целине, коначно, нематеријалне културе као што су фолклор, традиција, језик и усмена историја. Иако се бави материјалним и нематеријалним предметима, баштина је пре свега дискурзивна направа створена у врло одређеном историјском тренутку, што значи да је историјски производ одређене друштвене праксе. Баштина увек има друштвено значење, у које су уграђени односи моћи, идеологије, чија репродукција ствара дати дисциплинарни дискурс. Њена снага долази пре свега од процеса понављања (репродуковања) предмета изучавања, што доказује да је перформативни чин основ конституисања саме идеје баштине, без чега она не би једноставно ни постојала. ${ }^{11}$

11 Smith, Laurajane, The Uses of Heritage, London, 2006, 4 (preuzeto od : Jelena Stojanović, Imaginarni muzej vandalizma, ili od pamćenja do baštine, Prostori pamćenja, 2013, str. 195) 
У самом појму споменик (културно добро) уграђен је појам трајања, опомињања, хтења, говора који неће да занеми. Културно добро је сведок способан да претраје време.

Баштињење је, заправо, разумевање сведочанственог процеса у који улазе поједини (или одабрани), тзв. знаковити објекти и појаве, који припадају, превасходно, области систематског човековог деловања и стварања, тзв. добара, а на нивоу доктрине, оно је активност на очувању оног што се добија, што нас затиче као наслеђе. ${ }^{12}$ Наслеђено се мора не само очувати као целина доспелих вредности, већ и посвојити као ововремено и лично благо.

У обичају да се неке ствари издвајају и чувају, старом колико и цивилизација, смештена је човекова потреба да очува достигнуто сазнање стварности и себе у њој. Обичај стар колико и цивилизација други је назив за културу. Култура, стога није ништа друго до присуство памћења, а оно се темељи на сведочанствима.

Баштинска сврховитост подразумева целовито очување сазнања путем препознавања, чувања и употребе бића сведочанства, тј. сведочанственог ентитета: предмета и система односа забележених у њему. Херитологија је наука о вештини наслеђивања.

Баштинским установама (музеју, архиву, заводу, библиотеци, кинотеци, парковима и вртовима природе и открића и развоја ...) припада онај део ригидне производње сведочанстава, оних сведока са којих ће се скидати измаглице заборава. Ову неизбежну улогу баштинаријуми не могу да изведу сами, тј. без хармонизације са историјским (природним и друштвеним дисциплинама). ${ }^{13}$ Посланство баштинаријума, па тиме и музеја, библиотека, архива у савременом смислу део је умећа наслеђивања.

Документовање културне баштине је организован процес стандардизованог бележења информација које у својој сведочанствености носе предмети и целине баштине.

Баштинске установе су: установе без сврхе за зарадом које се оснивају да би обављале препознавање сведочанстава о значајним

12 Види: Булатовић, Драган, Баштинство или о незаборављању, Крушевачки зборник, 11/2005, стр. 8.

13 Isto, str. 15. 
феноменима у природи и друштву са задацима да прикупљају изразите носиоце документарности ради њихове трајне заштите, проучавања и употребе, а са циљем продубљивања сазнања у науци и унапређења образовања, што би развило културну понуду и обогатило уживања људи. У том смислу установе за бригу и коришћење баштине могу бити: музеји, библиотеке, архиви, кинотеке, институти за непокретну баштину, етно паркови и еко музеји, резервати, ботанички и зоолошки вртови, паркови научних и техничких открића и експлораторијуми као њихов развојни облик.

У систематизацији доктрине заштите поред сведочанствености као примарног својства, културних добара - као имена за њихове носиоце, културног наслеђа - као ознаке области збивања, баштина би могао да буде термин који би појмовно обухватао ментални и физички склоп сведочанствености добара у модусу наслеђа (patrimonium) као имања и обавезе меморијског и животно делатног третмана као очувања и продужења живота. А процес који систематски подржава хтење сведочења (остављања трагова) и остварује документа разабране поруке и преузете обавезе очувања спознатог и посвојеног, терминолошки доследно могао би бити: баштињење.

Наслеђе је категорија од одлучујућег значаја за постојање институција заштите, па тако и музеја. Аутори Кључних концепата музеологије крећу од дефиниције наслеђа у античком римском праву, према коме је оно, као patrimonium, означавало сав посед који су потомци наслеђивали од својих родитеља, и које се разликовало од оног имања које се стицало брачном везом. Девале и Марес овде уводе две аналогије, две метафоре, које су се родиле из појма патримонијума: 1. израз генетско наслеђе, које се односи на особине и квалитете који се преносе генетски; 2. концепт културно наслеђе, који се може пратити унатраг до 17. века и речит је сам по себи. Но, сам термин културно наслеђе добијао је током времена многа значења. Због своје етимологије, овај појам је - овде се поново уводи разлика између романског (франкофоног) и англосаксонског говорног подручја - опстао и у свом изворном значењу (филозофскијем, у романским језицима), а добио је и значење физичког поседа (практично, у англосаксонским културама). Данас су у употреби и појам 
патримонијума, односно наслеђа, и појам културног добра, али било како било, подсећају нас аутори, концепт наслеђа је неизбежно везан за могући губитак или нестанак и вољу и спремност да се наслеђе заштити и очува. ${ }^{14}$

У Србији је неопходно доношење једног општег Закона о културној баштини. Од времена Конференције у Гранади 1985. године (Европске конвенције и препоруке у области културног наслеђа Конвенција о архитектонској баштини - Савет Европе) ${ }^{15}$ превазиђен је приступ баштини редукован на заштиту у корист њене ревитализације. Законодавство у области споменика културе у Србији треба ускладити не само са Конвенцијом из Гранаде, него и са Смерницама очувања баштине Савета Европе из 2000. године. Оне су општеприхваћене у европским државама и све земље у транзицији које су приступале Савету Европе донеле су нове законе који регулишу ову област на исти начин.

Добра културне баштине нису, током историје, настала у једној, или постојећој заједници. Она су историјска баштина земље, односно народа. Стога земља, односно народ, преузимају одговорност за њихово чување које мора бити остварено према јединственим стандардима. Искуство европских држава показује да је начин да се то оствари увођење јединствене државне службе.

Значај дефинисања културног наслеђа, његовог стручног и научног тумачења, образовања у области наслеђа, као и његове заштите, конзервације, планирања, ревитализације, обнове и управљања њиме условљен је постојањем друштвене климе у којој је присутна свест о томе да дефинисање пута у будућност зависи од наше представе о сопственом пореклу - као појединца, групе или нације. Два главна културна императива Европе јесу: истицање посебности и разноликости националних, регионалних и локалних идентитета и препознавање онога што нам је као Европљанима заједничко. ${ }^{16}$

14 Milosavljević-Ault, Angelina, Nova muzeologija kao činjenica savremenosti, Kultura, 144/2014, str. 28.

15 http://www.bastina.eu/wp-content/uploads/2013/05/88556605-Evropske-konvencije-ipreporuke-u-oblasti-kulturnog-naslje\%C4\%91a.pdf

16 Види: Фулгоси, Александра, Вођење документације о културним добрима у светлу актуелних европских трендова, Наслеђе, Београд, 2013. 


\section{Литература}

Божић, Јадранка, Реанимација артефаката културне баштине као антипод репродукцији - Критичка реконструкција савременог дискурса сећања као централни, организациони појам савременог мишљења, Хоризонти светског и европског библиотекарства у дигиталном добу: зборник радова са међународне научне конференције, Београд, 27-28. октобар 2011. / [организатор конференције Библиотекарско друштво Србије] ; уредници Весна Црногорац и Весна Ињац, стр. 225-236.

Булатовић, Драган, Баштинство или о незаборављању, Крушевачки зборник, 11/2005, стр. 8.

Булатовић, Драган, Дигитализација као изазов бољем разумевању и коришћењу наслеђа, текст предавања (рукопис), 2014.

Илиева Николовска, Анита, Документација музејских колекција, Читалиште, 22/2013, 34-45.

Mercer, C., Which skills for culture in globalised and digitised world? U: European Cultural Forum, Brussels: European Cultural Forum, 2011, (uvodno izlaganje na European Cultural Forum, Brisel, 20-21 oktobar 2011.

Milosavljević-Ault, Angelina, Nova muzeologija kao činjenica savremenosti, Kultura, 144/2014, str. 28.

Остен, Манфред, Покрадено памћење: дигитални системи и разарање културе сећања-Мала иисторија заборављања, Нови Сад, 2005.

Popadić, Milan, Čiji je Mikelanđelov David?: baština u svakodnevnom životu, Beograd, 2012.

Smith, Laurajane, All Heritage is Intangible: Critical Heritage Studies and Museums, Reinwardt Academy; Amsterdam School of Arts, 2011, 23.

Smith, Laurajane, The Uses of Heritage, London, 2006, 4 (preuzeto od: Stojanović, Jelena, Imaginarni muzej vandalizma ili od pamćenja do baštine, Prostori pamćenja, 2013, str. 195.

Vukićević, Vuk, Digitalizacija kulturnog nasleđa u funkciji ostvarivanja ciljeva kulturne politike, Kultura, 130/2011, str. 165-182.

World Heritage Information, Kit, Paris: UNESCO World Heritage Centre, 2008, 5. 
Jadranka Božić

National Library of Serbia

\section{RECONSTRUCTION OF CULTURAL PROPERTY'S SOUL AND OUR EXPERIENCE OF HERITAGE IN PROCESS OF DIGITAL TRANSLATION}

\section{Summary}

Digitalisation is challenge to better understanding and use of heritage. Any legacy becomes one' s heritage only when someone recognizes basic properties of good in him. Adopt something like its heritage primarily indicates that memory of our past comes alive as reaffirmation of value of good and beauty. Cultural goods are marks of conservation humanistic upbringing personality. In algorithm, source files for musealisation represent basis for entering into process of reconstructing soul of cultural property and our experience of heritage as property. Availability of digital translation of any valuable content from the fund 's spiritual heritage is new experience, unmatched in history.

Kew words: legacy, heritage, cultural property, digitalisation, contemporary presentation of heritage, communication, animation, online availability 